\section{Sognet i opbrud}

\section{Om ændringerne i det kulturelle liv på landet $1950-70^{1}$}

\author{
AfGunnar Lind Haase Svendsen, antropolog, \\ ph.d.-studerende
}

\section{Indledning}

$\mathrm{P}$ aradoksalt nok kan besættelsestiden ses som det 20. århundredes kulmination på et traditionsrigt, dansk foreningsliv i landdistrikterne. Trods særdeles vanskelige, ydre omstændigheder stimlede folk sammen til møder i foredragsforeningen, i ungdomsforeningerne, i de nationale foreninger, til algang osv. På den måde blev en foreningstradition, der kunne spores tilbage til den klassiske andelstid i sidste halvdel af det 19. århundrede - ja, helt tilbage til deførste økonomiske sammenslutninger i de første årtier efter $1800^{2}$ benyttet som et redskab for civil mobilisering i modstanden mod besættelsesmagten.

For foreningsildsjælene af den ældre generation betød 1950'erne imidlertid et antiklimaks, en slags 'tømmermændenes' tid, hvor der i ungdomsforeningerne igen og igen blev talt om en forkælet, ansvarsløs og materialistisk indstillet efterkrigsungdom. ${ }^{3}$ "Under den tyske besættelse", lød en tidstypisk udtalelse fra højskolemanden J. Kr. la Cour Madsen i 1955, "oplevede vort folkelige og kulturelle arbejde en voldsom opblomstring. [Det var] på en måde gyldne dage for præster, lærere, politikere og højskolefolk, der rejste rundt og talte. Da var det fyldte sale, der ventede ved de talrige møder rundt i landet. [I dag] er meget anderledes."

Imidlertid kunne man end ikke i midten af 1950'erne gøre sig nogen forestilling om, hvor galt det skulle gå med kulturlivet på landet i løbet af 1960'erne - i det mindste anskuet ud fra en verdensopfattelse, der havde rod i besættelsestidens høje idealer.

Jeg vil i det følgende se nærmere på, hvor galt det egentlig gik med de kulturelle foreninger og institutioner på landet i løbet af det revolutionerende årti 1960'erne. På den ene side var der tale om nedlæggelse af talrige landsbyskoler, foredrags- og ungdomsforeninger, samt lignende kulturelle foreninger. Til gengæld oprettedes der mange ungdomsklubber, ligesom der opførtes talrige idrætshaller.

\section{Krisetid}

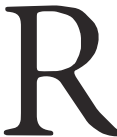

ent faktisk var krisen i foreningslivet ikke så alvorlig, som man ville gøre den til - i hvert fald ikke indenfor ungdomsforeningerne. Herom vidner samtidige statistikker. Dog var der en tendens til, at de unge i stigende grad søgte over i idrætsforeningerne (jf. figur 1). Dette skred fra åndskultur til kropskultur indenfor ungdomsbevægelsen fandt mange af den ældre generation beklageligt, ja, nogen så det ligefrem som et moralsk forfald, der - som en ungdomsleder udtrykte det - bundede i "biograf- og sportsmentalitetens udstråling fra stationsbyerne."

Ikke mindst artiklerne i De danske Ungdomsforeningers tidsskrift Dansk Ungdom vidner om, at mange landboere generelt oplevede perioden 1950 70 som en kulturel nedgangstid. 


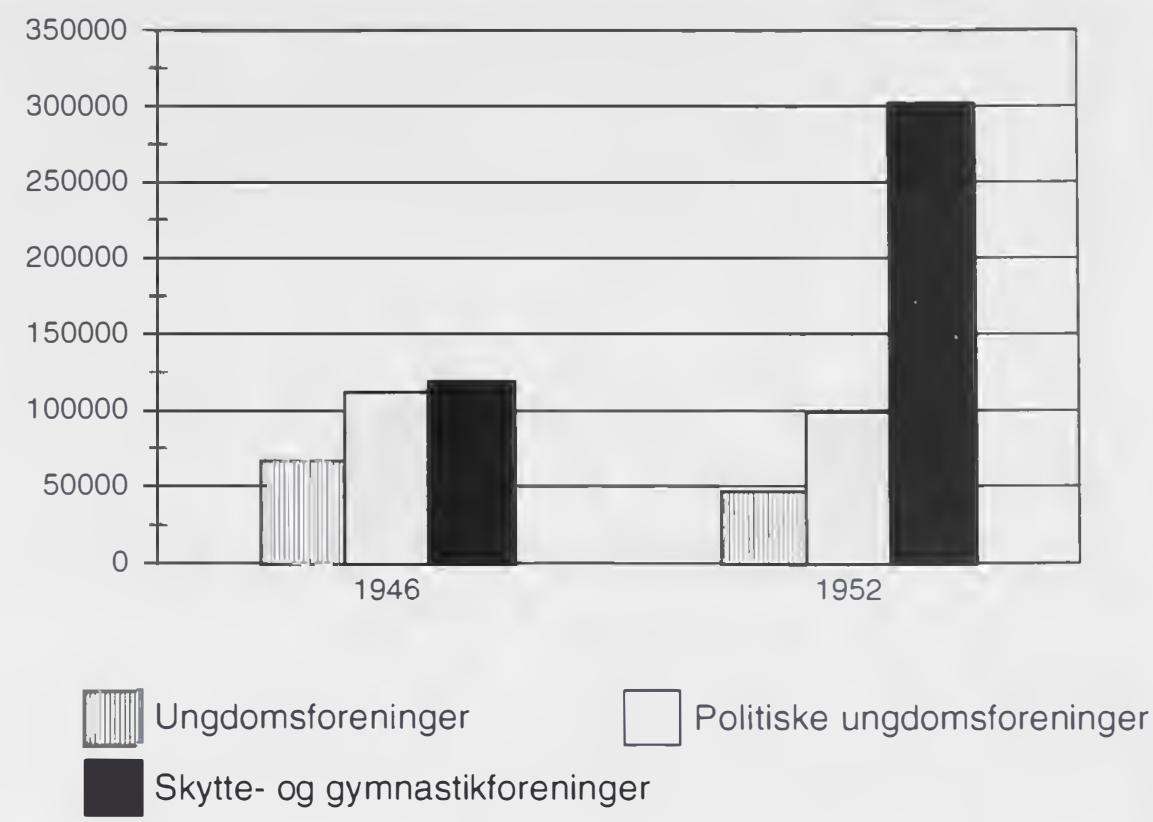

Figur 1: Medlemmer afungdomsforeninger, politiske ungdomsforeninger og skytte- og gymnastikforeninger i Danmark 1946 og 1952.

Kilde: Ungdomskommissionen 1952, s. 282 og s. $287 f f$.

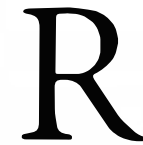

ent samfundsøkonomisk gik den såkaldte Udviklingen da også imod ond cirkel var plaget af afvandring og bortrationalisering af lokale økonomiske aktiviteter i form af nedlæggelse af gårde, mejerier, brugsforeninger foderstofforretninger mv. Ser vi bort fra egnsudviklingsstøt-

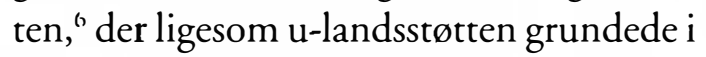
forestillingen om en gennem industrialisering opnået økonomisk vækst som udviklingens mål, var det fremfor alt byområderne, staten investerede $\mathrm{i}$ - investeringer, som befolkningen i de små landsbyer naturligvis var tvunget til at medfinansiere over skattebilletten.

Denne tendens blev ikke mindre markant omkring indførelsen af kommunalreformen i 1970. På dette tidspunkt fik også ændringerne indenfor kulturlivet et geografisk udtryk, ikke mindst i bebyggelsen. Ligesom de økonomiske fællesbygninger samt institutioner som sygehuse, plejehjem, banegårde, busstationer, offentlige kontorer mv. blev sogneskolerne nu efterhånden nedlagt, og med dem ofte også bibliotekerne. Herefter kom turen til rådhusene og, i flere tilfælde, forsamlingshusene. " "Det moderne samfunds fordele koncentreres $\mathrm{i}$ byerne", fastslog Hojskolebladets redaktør Poul Dam i april 1959. Derimod ville der ingen stordriftsfordele være i landsbyerne, hvorfor "grundlaget for en moderne fortsættelse af livet på landet" gradvist ville forsvinde."

\section{Landsbyskolen}

lle kilder vidner om, at landsbyskolen
traditionelt har fungeret som den
vigtigste fællesbygning for kulturelle 
aktiviteter. "I Hojskolebladets årgange fra århundredeskiftet og op i 1930'erne var det imidlertid friskolebevægelsen, der dominerede sammen med de beslægtede valgmenigheds- og frikirkebevægelser - for ikke at nævne den helt enorme interesse for Grundtvig. Ligesom de øvrige civile bevægelser byggede friskolebevægelsen på den selvorganisering kombineret med en indgroet skepsis overfor staten, som kan spores hos den danske landdistriktsbefolkning helt tilbage til det 19. århundredes sidste halvdel. Man sloges for det, man kaldte "hjemmenes ret", dvs. forældrenes ret til selv at opdrage deres børn, herunder også sørge for deres børns uddannelse. " Den nye centralskoleordning blev opfattet som en direkte trussel mod friskolerne og gav bl.a. derfor anledning til en heftig og til tider bitter debat, som kulminerede i 1938, da loven skulle gennemføres i praksis. ${ }^{12}$ Det viste sig her, at landbefolkningen var delt i to fløje:

„Landbefolkningen staar delt i to Lejre: For Centralskoler - mod Centralskoler....

Centralskolens Forkæmpere reklamerer med bedre Klassedeling og skoleteknisk set bedre Forhold i det hele, saa Børnene i de ældste Klasser vil kunne faa flere Kundskaber. Fra den anden Side svarer man igen ved at tale om den lange Skolevej og Tabet af den personligt prægede Undervisning i de smaa Skoler." ${ }^{\text {13 }}$

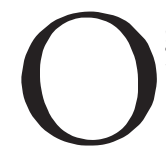
gså efter krigen blev der næret stor bekymring for landboungdommens uddannelse, hvilket ikke mindst afspejlede sig i et tidsskrift som Hojskolebladet. Således var der her i begyndelsen af 1950'erne mange, der - ligesom domprovst Jørgen Bøgh gav udtryk for i 1960 - frygtede for en generation af "nederlagsmennesker," forstået som en landboungdom, der på grund af for ringe uddannelse risikerede at blive overflødiggjort $i$ et moderne industrisamfund. ${ }^{1+}$

Også i forbindelse med en ny skolelovs vedtagelse i sommeren $1958 \mathrm{blev}$ landbefolkningen delt på spørgsmålet om centralisering eller lokalisering. "Strukturændringen i skolen" gav på dette tidspunkt anledning til en debat om realskolen, der i loven blev fremhævet som den overbygning til folkeskolen, der uddannelsesmæssigt skulle bidrage til at løfte landboungdommen op 'på niveau' med byungdommen. ${ }^{19}$

Omend der herskede en generel erkendelse af, at uddannelsesniveauet på landet var blevet for lavt, frygtede man dog også på uddannelsesområdet at blive inficeret af bylivet. ${ }^{16} \mathrm{Om}$ reaktionen på "en stigende udbredelse af de byprægede skoleformer" udtalte den allestedsnærværende ildsjæl indenfor andelsbevægelse, ulandsbistand, egnsudvikling mv., økonomiprofessor Poul Nyboe Andersen, i oktober 1958:

„Det er måske tilladt at sige, at der med tiden er opstået et skel i landbobefolkningen mellem to ganske vist ikke særligt klart definerede grupper. På den ene side en gruppe, som i overensstemmelse med den første generations højskolefolk så det som det vigtigste at fastholde de unge i en højt udviklet landbopræget kultur, og som derfor mente, at den unge var bedst tjent med efter folkeskolen at komme ud i praktisk arbejde og derefter afrunde sin uddannelse gennem ophold på højskole og landbrugsskole. På den anden side var der så en gruppe, som måske ikke havde noget særligt forhold til den folkelige kultur [og som mente, det] var nødvendigt at give dem en skoleuddannelse, der i så høj grad som muligt stillede dem på 


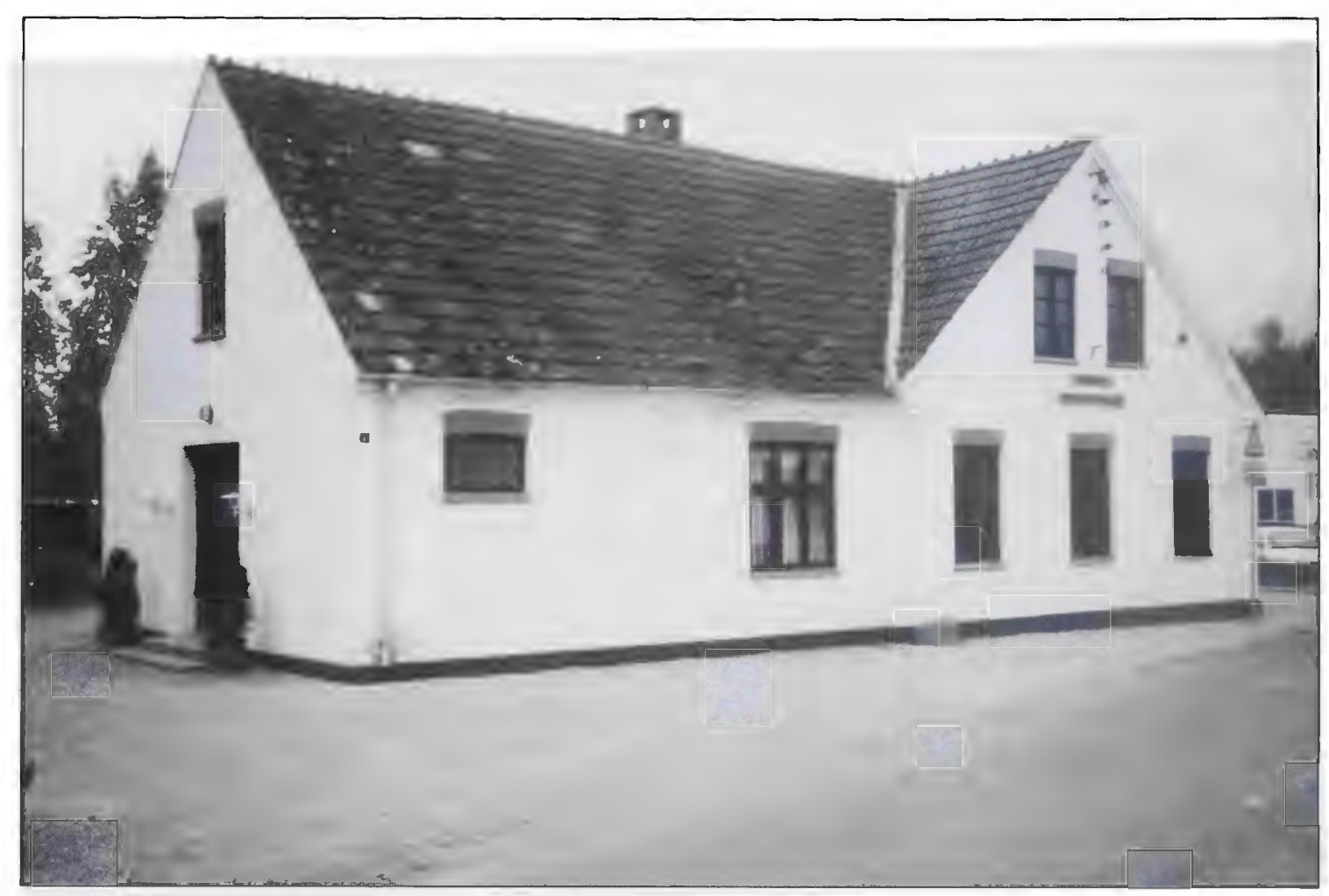

Havnelev forsamlingshus.

lige fod med de unge fra byerne." ${ }^{-}$

I centraliseringsdebatten indenfor andelsbevægelsen op gennem 1960'erne tog den strengt rationelle økonom Nyboe Andersen klart modernisternes parti, idet han ligesom landboforeningernes Anders Andersen beklagede, at der var sket et skred i udviklingen, som ikke kan skrues tilbage. ${ }^{18}$ Imidlertid fremtrådte den landboprægede Venstremand Nyboe Andersen indenfor det kulturelle område i højere grad som en mægler mellem modernister og traditionalister, dvs. mellem landboere der ønskede at forandre og landboere, der ønskede at bevare. Ligesom Poul Dam nærede han således frygt for den lille landsbys undergang, hvilket hans engagement $\mathrm{i}$ egnsudviklingsdebatten også vidner om. "Udviklingen har sine alvorlige skyggesider",

hed det i en artikel i Hojskolebladet fra april 1959, hvor Nyboe Andersen gav udtryk for sin bekymring for de revolutionerende forandringer i de danske landdistrikter.

"[Landets] hårdt betrængte livsform rummer værdier, som den sejrende bycivilisation ikke kan byde på. De små lokale enheder giver gode voksemuligheder for personlige kontakter ansvarsbevidsthed overfor andre og effektivt folkestyre. Hele den standende diskussion om det moderne menneskes rodløshed og ensomhed i velfærdsstaten står i nøje sammenhæng med byens fremtrængen på sognets bekostning."14

I

midlertid - glattede han straks ud havde bilismen på afgørende vis bidraget til at "nedbryde den lokale isolation" og her igennem udjævne forskellen mellem livsvilkårene på land og i by. ${ }^{20}$ 
I midten af 1960'erne var der dog flere landboere, der netop klagede over den tiltagende ensomhed, som f.eks. en husmandskvinde, der i 1966 udtalte, at "vi lever ret isolerede på landet i dag, der er ikke det fællesskab som i gamle dage, og det kan godt knibe med kontakten." 1

Det var ikke mindst nedlæggelsen af sogneskolerne, der satte yderligere gang i den onde cirkel. Skolerne havde tydeligvist været et lokalt mødested, hvor bekendtskaber blev indledt, kontakter blev knyttet, aftaler blev indgået, ligesom skolen havde haft en vigtig funktion som et kulturelt centrum. I 1959 beskrev gdr. Tage Rosenstand denne skolernes 'udvidede' funktion på følgende måde:

"Skolerne, som de ligger i vore landsbyer, har oftest været små kulturcentre. Læreren er ofte leder af ungdomsarbejdet, holder aftenskole, leder sangen til sammenkomster og gilder og tager virksomt del $i$, hvad der foregår af fællesliv i landsbyen. - Skoleloven af 1958 vil mange steder lægge sig hindrende i vejen for en fortsættelse heraf. Der er en bestemmelse i loven, der siger, at de børn, der vil læse videre ved en eksamensskole efter skolepligtens ophør, skal undervises i tysk og matematik i det 7. skoleår. Denne bestemmelse volder mange vanskeligheder rundt $\mathrm{i}$ kommunerne, så man må enten helt ophæve skole eller gøre den til en forskole." 22

\section{A ter andre udtrykte sig i endnu skarpere vendinger, som "bonde 1 Ldatteren" fra Præstø amt, Else} Toftkjær Jensen, der i april 1959 mente, at "skolecentraliseringen vel er et af de virksomste midler til udslettelse af det kulturmønster, som hidtil var landets. Kan I dog ikke se", fortsatte hun, "at I nu er i fuld gang med at lave sovebyer også på landet?
De gamle og syge flytter man til skrapt centraliserede alderdoms- og plejehjem og hospitaler, og børnene til næsten lige så centraliserede skoler." ${ }^{23}$

\section{Kommunalreformen}

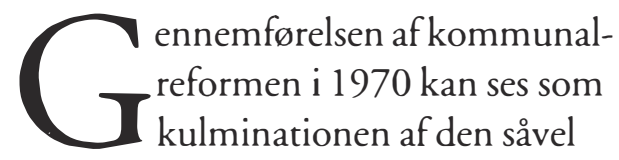
organisationsmæssige som fysiske bortrationalisering af økonomiske og kulturelle aktiviteter ude i landområderne. Reformarbejdet var blevet sat i gang i det på mange måder skelsættende år 1958 med nedsættelse af en kommunallovskommission, der skulle komme med forslag til såvel en ny inddelings- som styrelov. ${ }^{24}$ Den deraf følgende inddelingslov, der blev vedtaget i Folketinget den 18. maj 1967, havde til hensigt at samle land og by indenfor kommuner, som typisk var centreret omkring ét bysamfund. ${ }^{25}$

I modsætning hertil havde den gamle kommuneinddeling fra 1841 været baseret på en opdeling af landbrugslandet Danmark med en sogneinddeling, der kunne spores helt tilbage til middelalderens kirkeområder. ${ }^{26} \mathrm{Nu}$ blev 25 amtskommuner erstattet af 14 amtskommuner samt Hovedstadsområdet, mens 86 købstadskommuner samt 1300 sognekommuner blev afløst af 273 nye kommuner (ekskl. Københavns og Frederiksberg kommuner).

Omend disse nye kommuner i perioden 1964-70 formelt blev etableret på frivillig basis, var der ligesom i forbindelse med skolenedlæggelserne en ikke ubetydelig modstand mod reformen blandt landbefolkningen.

Debatten, der syntes at kulminere i 1966, afspejler sig tydeligst i Hojskolebladet men dukker dog også op i landbotidsskrifter som Husmandshjemmet. ${ }^{27}$ Således 


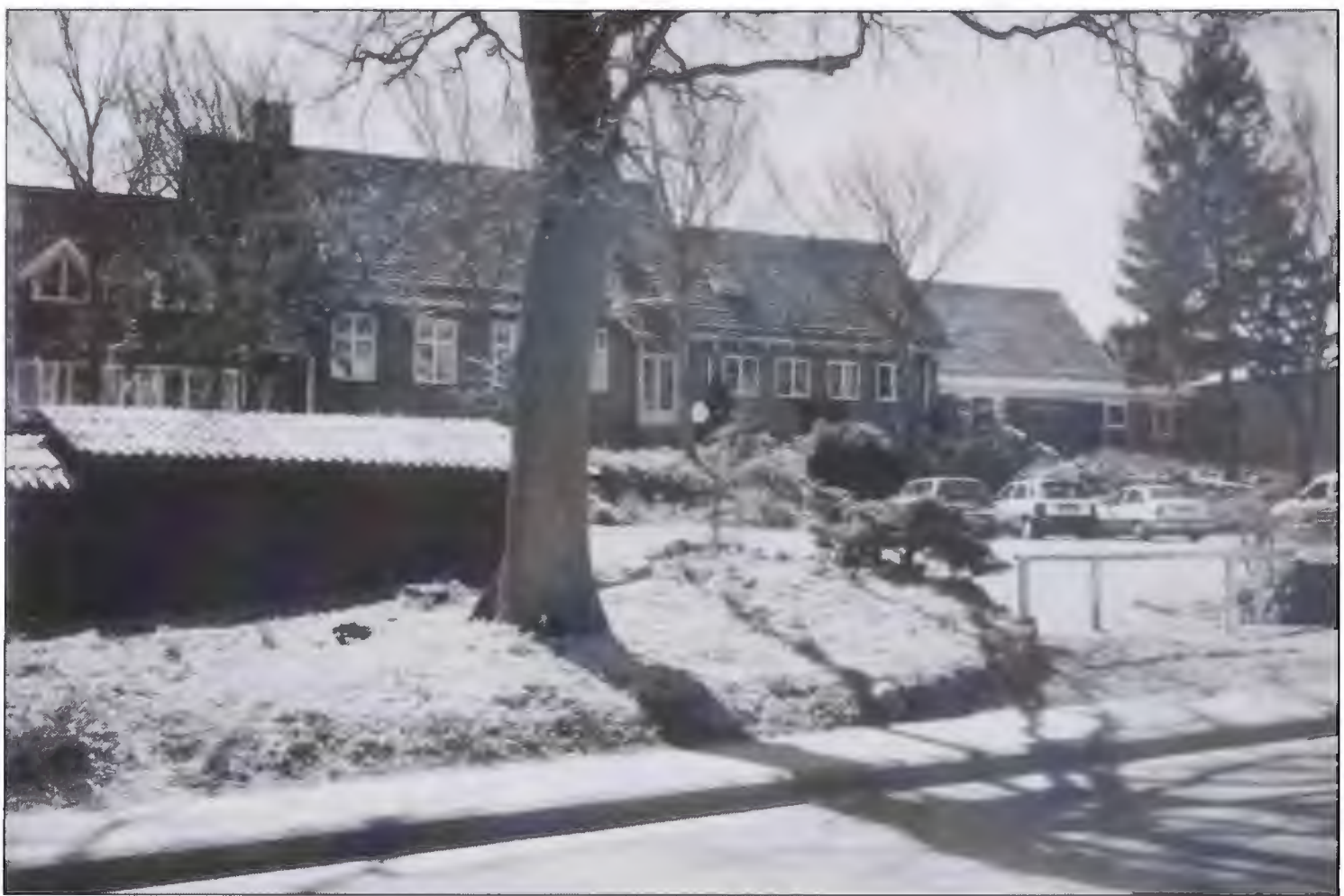

Ryslinge Friskole

blev der i Husmandshjemmet i en artikel fra marts 1966, "Kommuner lagt sammen til den store guldmedalje," talt om "psykosesammenlægninger," mens medredaktør af Hojskolebladet, Askov-læreren Uffe Geertsen, samme år røg ud i en heftig diskussion med sin kollega fra Askov højskole, Niels Højlund. Mens Højlund primært var positivt indstillet overfor en inddeling, som kunne modvirke "sognepatriotisme", foretrak Geertsen "en mere decentralistisk og dermed mere demokratisk løsning." ${ }^{28}$ Sidstnævnte, der i øvrigt stillede et stort spørgsmålstegn ved sammenlægningernes påståede frivillighed, frygtede ikke mindst, at landboerne ville blive revet ud af en tidligere meningsfuld og sammenhængende landbotilværelse:

„Det kan (..) ikke nægtes, at man, belært af erfaringen, maa frygte, at i de nydannede storkommuner vil børnene fra yderdistrikterne blive proppet i skolebusser og sendt ind til centralbyens gigantskole, ligesom de gamle vil blive samlet i centrale alderdoms- og plejehjemskaserner, - hvilket betyder, at baade børn og gamle bliver revet ud af deres sociale sammenhæng netop i de perioder af deres tilværelse, hvor de allermest kunne have brug for at forblive i denne sammenhæng. ${ }^{29}$

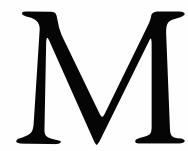
ed gennemførelsen af den nye kommuneinddeling blev den proces, man siden begyndelsen af 1960'erne havde kaldt "sognet i opbrud", for alvor materialiseret i kulturlandskabet og i bebyggelsen. ${ }^{30}$ Således var en kulturel urbanisering omkring 1970 blevet indskrevet i lovgivningen, bl.a. i form af skolelovene af 1937 og 1958 og fritidsloven af 1969, mens en fysisk urbanisering efterhånden også fik hjemmel i lovgivningen, bl.a. i kraft af de reviderede jordlove, egnsudviklingsloven, samt kommunalreformen. Derimod 
syntes land- og byzoneloven fra 1969 ud fra et overordnet landsplanlægningsperspektiv at reintroducere den skarpe opdeling mellem land og by ved, meget statisk, at fastholde en opdeling i byzone, sommerhusområder og landzone, en opdeling der dog kun yderligere bidrog til at marginalisere de mindste lokalsamfund.

\section{Den nye bebyggelse}

\section{Byen Danmark: parcelhuskvarterer}

\section{og sommerhuse}

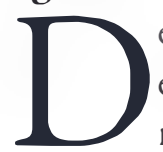
et var naturligvis ikke alle landboere, der følte sig handlingslammede i tiden omkring kommunal- reformen. Især i de større landsbyer - og her ikke mindst i de landsbyer, hvor centralskolerne blev placeret - forsøgte man således fra omkring midten af 1960 'erne og op gennem 1970'erne at undgå en befolkningstilbagegang ved at udstykke parcelhuse.

Disse nye parcelhuskvarterer, der allerede i løbet af 1950'erne var skudt op i de større byer, bredte sig nu også i landområderne på bekostning af den agrare bebyggelse (se figur 2). Kvartererne tiltrak først og fremmest børnefamilier, hvor forældrene ikke sjældent var pendlere.

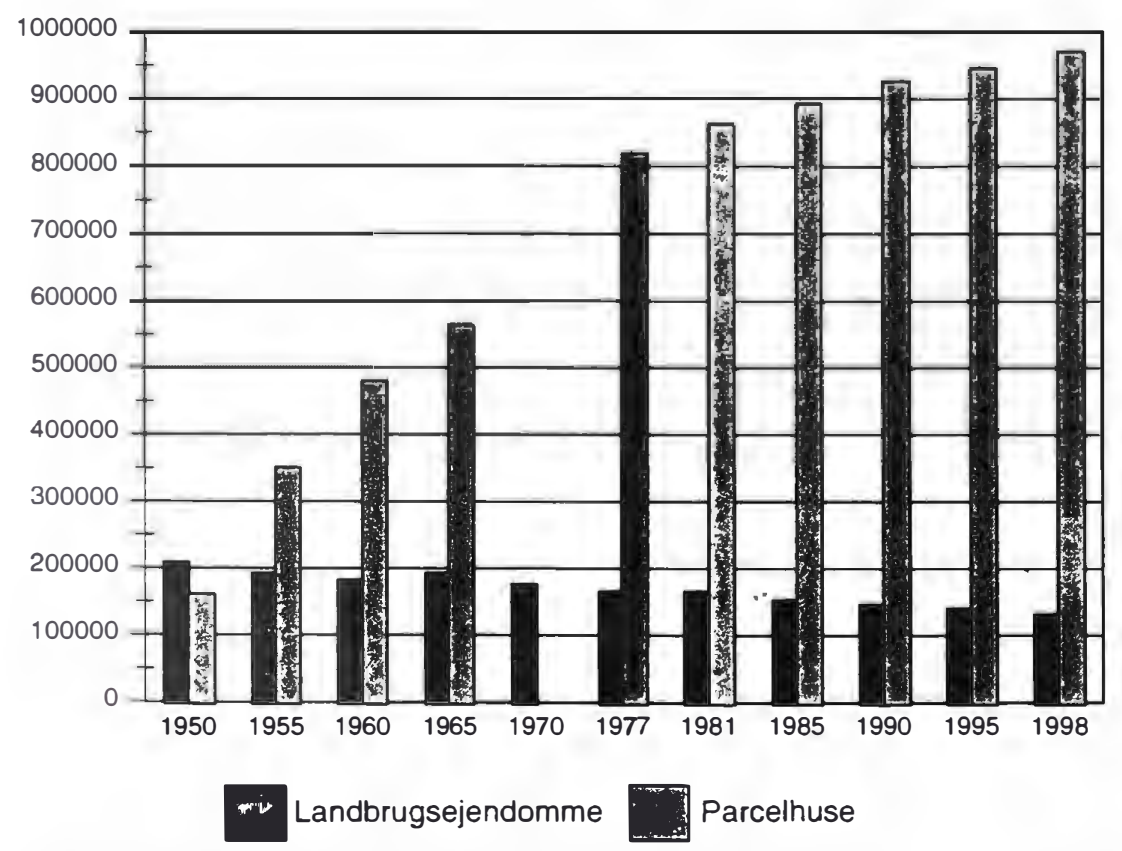

Figur 2: Antal landbrugsejendomme og parcelhuse i Danmark 1950-98, i tusinder.

Kilde: Statistiske airboger, tiairsoversigter

Note til kurven, der viser udviklingen i parcelhuse: I 1950 er tallet angivet for det samlede antal "villahuse", i 1955 for det samlede antal "fritliggende enfamiliehuse". I perioden 1960-1981 er angivet tal for kategorien "enfamiliehuse". Fra og med 1985 er angivet tal for kategorien "parcelhuse". 
$\mathrm{E}$ t eksempel på en driftig by er den af Palle O. Christiansen beskrevne landsby Toksværd i Toksværd sogn på Sydsjælland, hvor man allerede i 1950'erne kom til en erkendelse af, at det var "nødvendigt fra kommunal side at gøre noget aktivt for ikke at sakke bagefter." ${ }^{31}$ Den bebyggelsesmæssige oprustning til de nye tider blev tidligt indledt med opførelsen af et plejehjem i 1954, samt en centralskole for hele sognet i 1961, som i høj grad kom til at fungere som fælles mødested for beboerne. ${ }^{32} \mathrm{Om}$ tankerne om større parcelhusudstykninger hedder det:

„Sognerådet havde været foruroliget over det faldende befolkningstal i 1950'erne, men i perioden 1960-65 faldt folketallet med ca. 20 personer hvert år. Sognet var på vej til at blive en "pensionistkommune". Samtidig havde man p.g.a. de store skoleudgifter i høj grad brug for et stabilt og helst forbedret skatteunderlag (..) Flere i det nye sogneråd så det også som deres opgave at prøve at få fyldt skolen ud, således at man ikke kunne påstå, at den var overdimensioneret. ${ }^{\text {"33 }}$

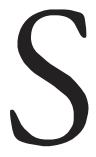
om så mange andre steder var der på dette tidspunkt ikke tale om den store planlægning. Man udstykkede hurtigt 70 boliger, og forsøgte at lokke købere til med billige priser. ${ }^{34}$ I 1964 flyttede den første familie ind, og i 1973/74 var kvarteret fuldt udbygget, hovedsageligt af de unge, erhvervsaktive familier med børn, man fra begyndelsen havde håbet på ville trække til byen. ${ }^{35}$

Denne offensive, sognepolitiske strategi blev yderligere skærpet i 1969, da man planlagde et større lokalcenter med en bebyggelse, der skulle rumme 840 nye mennesker idet - som nogle angav som begrundelse - "udviklingen gjorde det nødvendigt at følge med." ${ }^{36}$ Den egentlige baggrund for denne ambitiøse plan (der i øvrigt aldrig blev realiseret) var, at man ved kommunesammenlægningen frygtede at blive et udkantsområde:

„Ved at vedtage en ambitiøs plan som den omtalte for sammenlægningen håbede man at kunne binde kommunalbestyrelsen [for den nye centralkommune] i Holmegaard til en vis udvikling øst for Fensmark, eller i det mindste at gøre kraftigt opmærksom på, at Toksværd ikke ønskede at forblive uberørt af den "udvikling", som fandt sted i større kraftcentre." ${ }^{37}$

$\mathrm{I}$ de mindre, tilstødende landsbyer, Gødstrup og Dysted, hvor centralskolerne og parcelhuskvartererne ikke var blevet anlagt, var det straks sværere for beboerne at planlægge overlevelsesstrategier. Ikke mindst Dysted er her et eksempel på handlingslammelse og opløsningstendenser på grund af nedlæggelsen af de fælles institutioner. Således lød de karakteristiske kommentarer i forbindelse med nedlæggelsen af skolen i 1961: "Vi var stumme. Det nyttede jo alligevel ikke noget. Det var jo udviklingen." ${ }^{38}$

Hvor det som oftest var Udviklingen, der fik skylden for nedlæggelsen af skoler, mejerier, detailhandel, håndværk osv., blev udbredelsen af en anden form for urban bebyggelse op gennem 1960'erne sommerhusene - overraskende nok tilskrevet menneskene selv. Her var der simpelthen tale om dårlig planlægning. Modsat parcelhusbyggeriet gav sommerhusbyggeriet næring til en reel udviklingsfrygt hos landdistriktsbefolkningen. Man var bange for, at landskabet skulle blive plastret til med sommerhuse og hermed blive forvandlet fra et natur- eller produktionslandskab til et rekreativt landskab for bybefolkningen. 


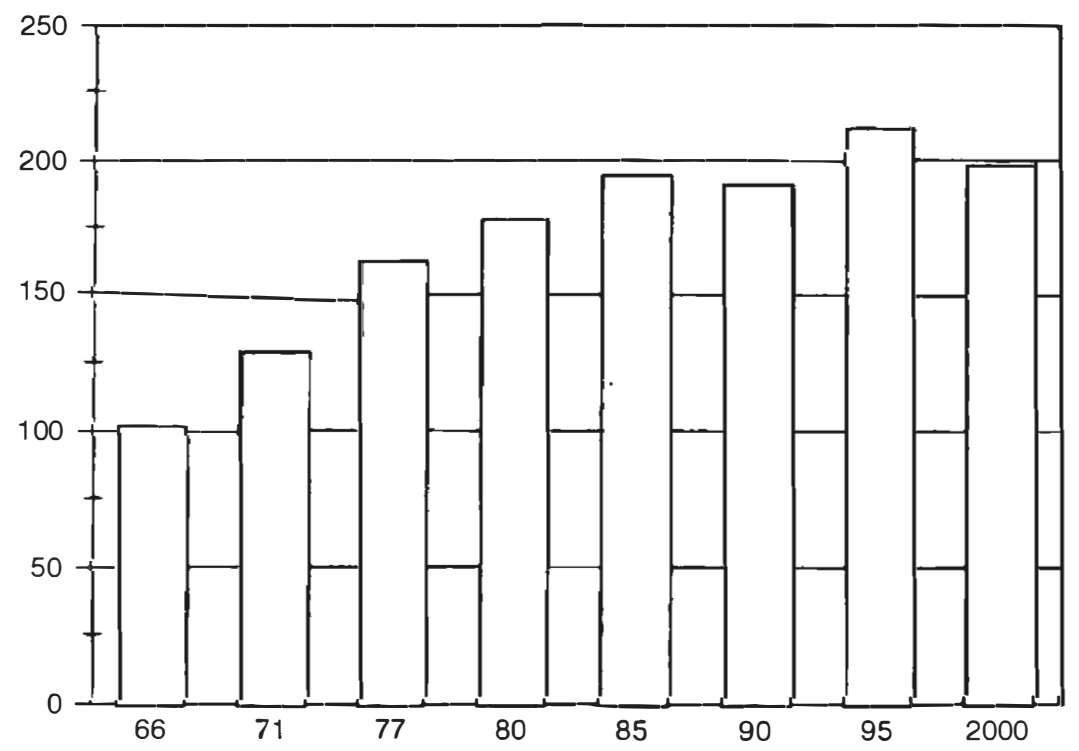

Figur 3: Antal sommerhuse i Danmark 1966-2000, i tusinder.

Kilde: Statistiske årboger, forskellige ärgange.

"Når byerne vokser (..) må mange landbrugsejendomme vige for boligbyggeri," beklagede således formanden for Herstedernes Husmandsforening nord for Tåstrup, statshusmand Frede Andersen, i april 1964. „Andre ejendomme," fortsatte han, "omdannes til gartneri - og de, der bliver tilbage, får deres glæde til naturen ødelagt." "'" På lignende vis fastslog skovrider Sten Bjarke i Husmandshjemmet i april 1968, at landboerne atter var blevet taget ved næsen af "89-dages-københavnere," der ikke havde været sene til se en god forretning $i$ at forvandle tidligere rurale områder til rekreative områder for turister fra byerne, bl.a. med et "planløst sommerhusbyggeri" til følge. ${ }^{(1)}$

Også mange andre stillede sig kritisk overfor bybefolkningens ekspanderende boligforbrug, som nu også rakte ud på landet. Nu skulle man ikke blot partout have egen bil, skrev Knud Bidstrup i 1963 nu skulle alle også have sommerhus. Ligesom det var tilfældet med 1950'ernes 'befolkningseksplosion', gav statistikernes fremskrivninger her anledning til skrækvisioner. Således skulle man omkring år 2000 have omkring 1 million sommerhuse i Danmark, var det blevet spået i landsplanudvalgets Zoneplan for Danmark 1962.41 En katastrofal planlægning, mente Bidstrup.

„Vi har vel i dag godt 100.000 sommerhuse, men egentlig syner de af meget mere. Det skyldes den store spredning og den næsten konsekvent uheldige placering $\mathrm{i}$ landskabet. I vor begærlighed efter at sikre os en parketplads i naturen ødelægger vi naturen både for os selv og andre. Får denne tendens lov til at fortsætte, vil Danmark efterhånden blive pindet ud i parcel- 
monarkier med sommerhuse på alle bakketoppe, hvorfra beboerne kan sidde og nyde udsigten til hinanden. ${ }^{42}$

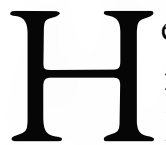

ermed mente Bidstrup, man rent fysisk-geografisk nærmede sig en komplet forvandling af bonde-

landet til et "civilisationstæppe." 43 Således, spåede Bidstrup med stor visionær kraft, ville Byen Danmark blive realiseret - en by uden geografisk eller politisk grænse, en by der én gang for alle ville ophæve skellet mellem land og by. Byområderne ville nemlig brede sig, indtil byen var "intetsteds og allevegne." ${ }^{4+}$ Hermed materialiseredes en kulturel urbanisering i det geografiske rum som en fysisk urbanisering.

„[Selv om] det lykkes at genskabe [grænsen mellem land og by] må vi ud i en fjern fremtid forestille os Danmark forvandlet til én stor by - ganske vist en åben by med vidtstrakte grønne områder mellem tætbebyggelserne, men alligevel ét byområde, bundet sammen af hurtig kommunikation og nært arbejdsfællesskab og befolket af mennesker, som uanset erhverv lever og tænker bymæssigt. Den vej går det støt og sikkert i alle højt udviklede lande. ${ }^{~}{ }^{+}$

\section{Sognegårde og idrætshaller}

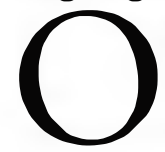
gså indenfor det rent kulturelle område var der aktiviteter at spore op gennem 1960'erne i de lidt større landsbyer. Dette bevidnes af artiklerne i Dansk Ungdom og Hojskoleblader, der i høj grad domineredes af den samme 'slægt' af evolutionistisk inspirerede begreber, der gjorde sig gældende indenfor det økonomiske foreningsliv, selvom tidsnøden tydeligvist var mest udtalt i de økonomiske foreninger. ${ }^{\text {th }}$

Således medførte "udviklingen", "rationaliseringen", "nødvendighedens lov" mv. også her centraliseringstendenser i form af en "strukturændring i foreningslivet" - en strukturændring, der ligeledes satte sig spor i form af foreningssammenlægninger og, $\mathrm{i}$ sidste instans, i bebyggelsen. ${ }^{-}$

I 1950'erne og 1960'erne var det ikke mindst det såkaldte fritidsproblem, der gjorde det svært at holde på en landboungdom, der såvel kulturelt som erhvervsmæssigt i stigende grad orienterede sig mod

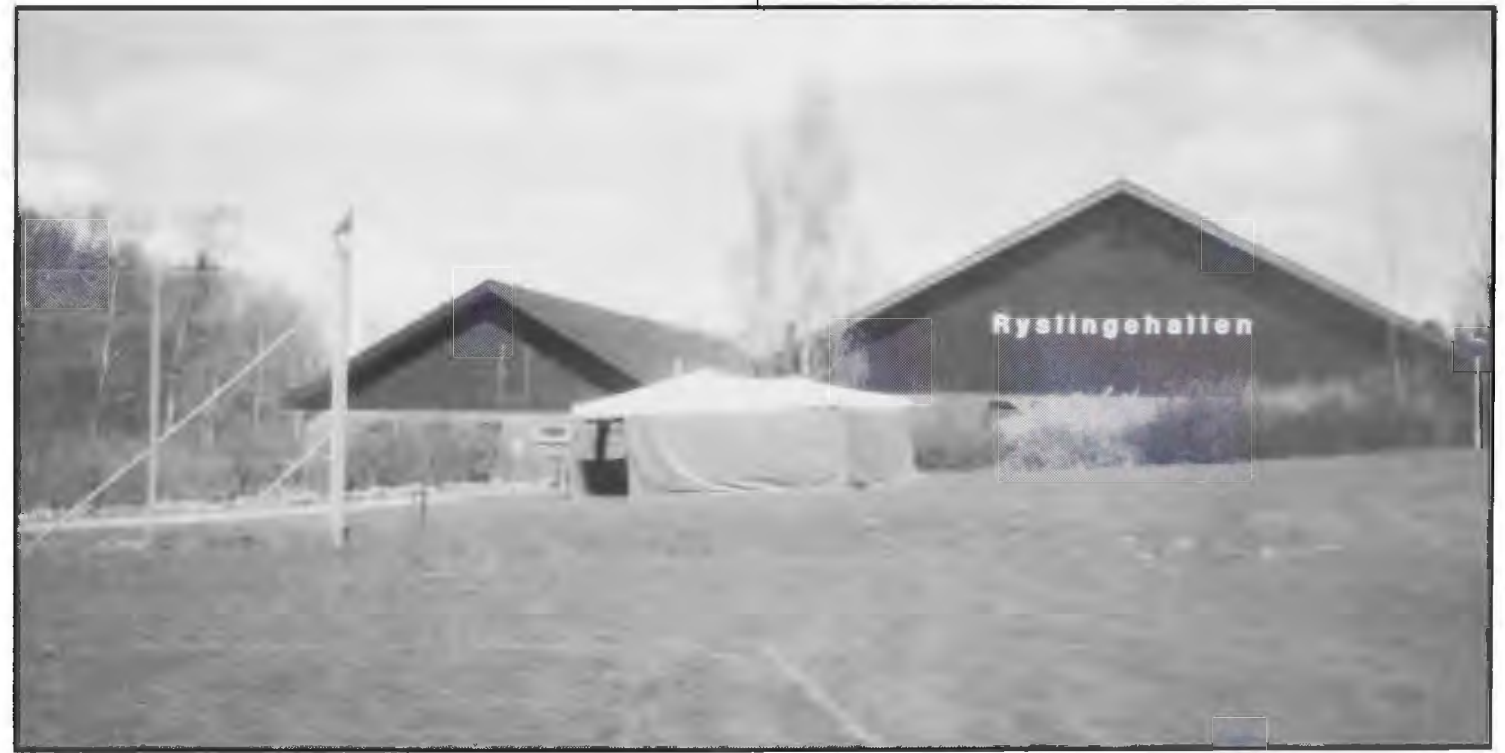

Idratshal. Ryslingehallen. 
byerne. ${ }^{4 \gamma}$ På den måde kan man sige, at hvor 'drivkraften' bag udviklingen indenfor det økonomiske samarbejde blev set som ændringer i internationale markedsforhold, blev den indenfor det kulturelle område set som den til stadighed øgede fritid, ikke mindst blandt ungdommen. ${ }^{+3}$

Fra midten af 1960'erne havde det organisatoriske svar på strukturændringen været at sammenlægge lokale ungdomsforeninger, ligesom man flere steder sammensluttede ungdomsforeningerne med

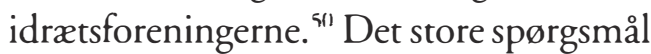
var nu, hvorledes centraliseringen af det kulturelle foreningsliv skulle manifestere sig i bebyggelsen.

Siden 1920'erne havde der indenfor ungdomsforeningerne været en debat om forsamlingshusenes forfald. ${ }^{51} \mathrm{En}$ del af landbefolkningen havde ment, det kunne svare sig at modernisere de gamle forsamlingshuse, mens andre mente, at opkomsten af et "fritidssamfund" krævede en investering i moderne, tidssvarende kulturcentre ude i sognene. ${ }^{52}$

Det synes at have været en kombination af 1937-skolereformen og kritikken af forsamlingshusene som utidssvarende, der i første omgang havde næret ideen om kulturelle egnscentre. ${ }^{53}$

Allerede i 1940 blev ideen om egnsgården lanceret - en selvejende institution forsynet med køkkenhave, marker, køkken m.m., der skulle formidle landbrugsfaglig viden til ungdommen og her igennem fungere som et "bolværk" mod ungdommens vandring fra land til by. ${ }^{9 i}$ Herudover skulle egnsgården eller sognegairden fungere som egnens kulturelle centrum, idet den skulle fungere som en art 'udvidet' forsamlingshus med forsamlingslokaler, gymnastiksale, friluftsbad, bibliotek, studiekredslokaler fremvisning af film samt teaterscene. ${ }^{55} \mathrm{I}$
1941 var der en sognegårdsudstilling i

Fredericia, hvor de nævnte kulturelle faciliteter var kombineret med skole, lige såvel som sognets administration og sognerådets mødesal tænktes henlagt til sognegården. ${ }^{56}$ Aret efter, i 1942, blev ideen om en sammenlægning af skole-forsamlingshusgymnastiksal-festsal for første gang realiseret med indvielsen af Revninge Sognegård i landsbyen Revninge syd for Kerteminde, mens kombinationen skole-forsamlingshussogneadministration blev realiseret i Sjørslev Kommunes Sognegård i landsbyen Sjørslev mellem Viborg og Silkeborg. ${ }^{57}$

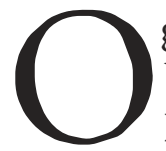
gså den indflydelsesrige Ungdomskommission, anført af Hal Koch, betragtede sognegården som et naturligt centrum for sognets kulturelle liv - et synspunkt, der blev fremsat i 1951-betænkningen Fritidslokaler på landet. ${ }^{58}$ Således blev snart sagt ethvert forhold i forbindelse med planlægning og opførelse af sognegårde grundigt beskrevet som arkitektur, finansiering, driftsøkonomi, beliggenhed osv.

I takt med sognegårdenes udbredelse steg imidlertid bekymringen for, at en centralisering af kulturlivet ville trække ungdommen bort fra hjemmene - lig den bekymring, der havde hersket i tiden omkring Første verdenskrig, da man i ungdomsforeningerne havde frygtet for en rod- og hjemløs ungdom. "' Dette gav bl.a. en højskolelærer fra Rønshoved højskole, Asbjørn Mandøe, udtryk for i kronikken "Sognegården - ønskedrøm eller mareridt?" i Jyllandsposten juni 1951.(1)

Efterhånden syntes De danske Ungdomsforeninger dog nærmest hægtet af de lokale debatter om sognegårde. Man forholdt sig generelt tøvende overfor 


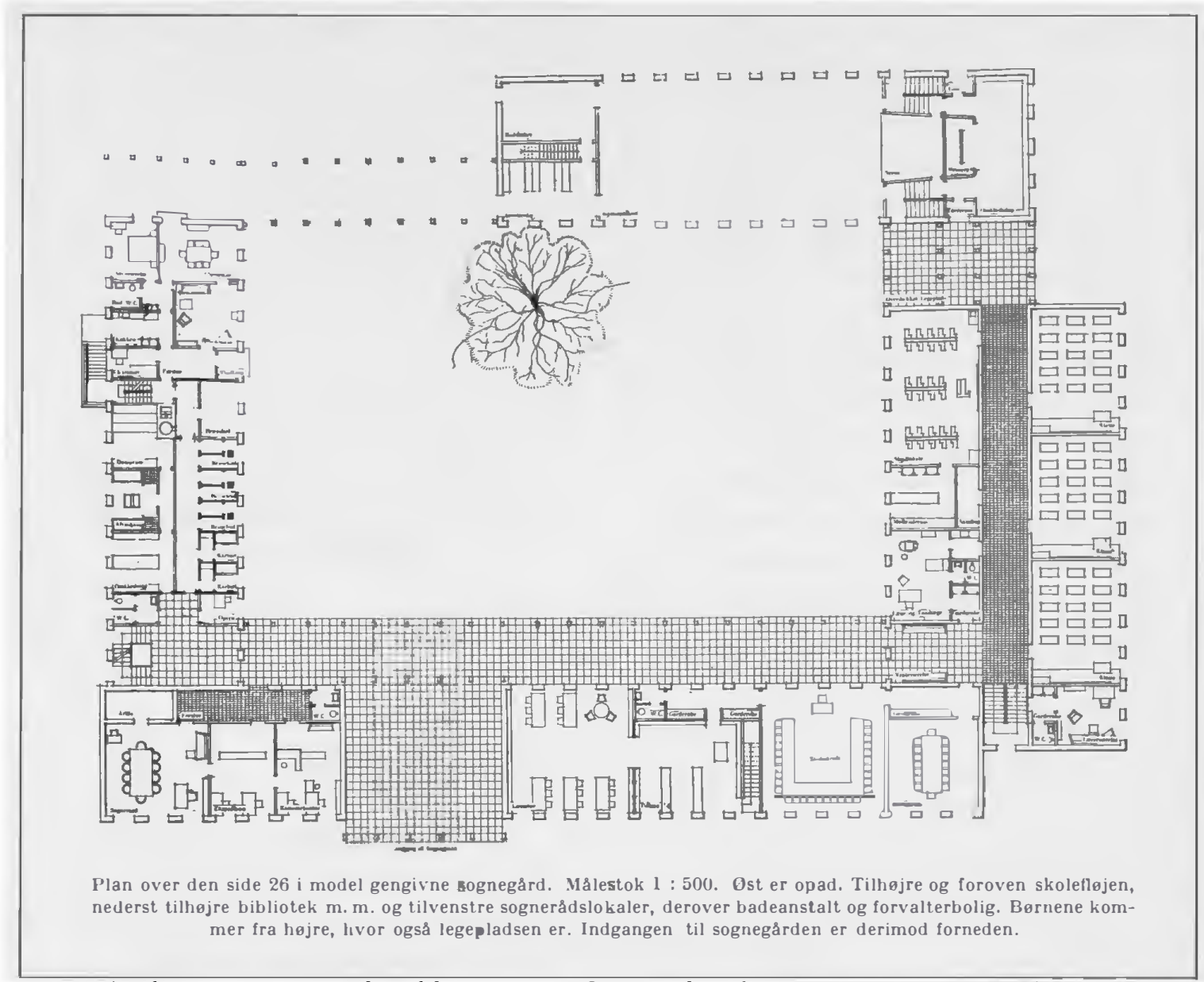

Figur 4: Plan over sognegård. Kilde: Gengivet fra Ungdomskommissionen 1951, s. 68.

sådanne nymodens opfindelser, der medførte en forvandling af ungdomsforeningerne fra kulturelt-kristne foreninger til mere underholdningsprægede hobby-, fritids- og ungdomsklubber. Ligesom man i forbindelse med statsstøtten havde harceleret mod en krævementalitet, frygtede man her et skifte over mod en "barnepigementalitet" - ja, ungdomsklubberne blev af nogle ligefrem set som "en fare for demokratiet."

Imidlertid var der blandt mange ungdomsledere omkring 1960 en erkendelse af, at foredragenes tid var ovre, og at ungdommens øgede fritid krævede nye og anderledes fritidslokaler. ${ }^{62}$ Det var her vigtigt, mente flere, at de unge selv skabte deres fritidslokaler. Således fortalte lærer
Viggo Vandkær Thomsen om, hvorledes man indrettede en fløj af den nedlagte skole i Ødis til ungdomslokaler i 1960. "Etableringen har de unge selv betalt. Arbejdet har de selv udført. Til driften betaler de hver en daler pr. måned. Altsammen har det givet et tilhørsforhold, som man ikke skal undervurdere." 63

\section{Også op gennem 1960'erne} dominerede den mere traditionalistisk indstillede fløj i ungdomsforeningerne. Man kunne tilsyneladende fjerne alle fællesbygningerne indenfor det økonomiske samarbejde - men kirkerne og forsamlingshusene skulle man ikke røre ved! Således fremsatte lærer Peter Madsen, Løgumkloster, i 1966 følgende, karakteristi- 
ske kritik af de nye kulturcentre, som var blevet foresläet oprettet af et udvalg under Ministeriet for kulturelle Anliggender i december 1963:

"Charmen ved vore folkelige, kulturelle foreninger er (..) folelsen af en personlig kontakt de enkelte medlemmer imellem. Et kulturcenters funktion vil blive ex kulturelt supermarked uden mulighed for tilstedevexrelse af et personligt praxg. ()prettelsen af kulturcentre vil bevirke de aktive forsamling huses forfald, da arbejdet med hensyn til det folkelige og kulturelle i ojebliktet befinder sig i et hamskifte, der ikke täler forstyrrelse af nogen art."

$\mathrm{I}$

stedet var det nu idratsforeningerne, der tog têten. "Tiäret, hvor de store halbyggerier fandt sted" kunne begynde." "I ) isse haller blev af nogle hilst velkommen som "en nye tids samlingshuse", som det hed i en leder i 1 )ansk (Jngdom og ldrat i 1967, omend man samme sted betonede, at der skulle vere plads til "det andet, som gymnastpionerernes generation havde så åbent et sind for." "to

Atter andre så halbyggeriet som en endelig manifestation af den kulturelle urbanisering af landdistriktsbefolkningen, der var foregäet siden Anden verdensk krig. Saaledes fastslog Flemming Hemmersam, Ribe, i 1967, at der var kommet en "ny" mentalitet" ude pa landet i form af en "bykultur", som bla. de nyelarere på landet reprasenterede. Sammen med de kulturlose' idratsforeninger var disse - ifolge Rindal-tilhangerne - overlegne, finkulturelle byfolk i faerd med at udkonkurrere ungdomsforeningerne:

"[Skal pengene] ga til gymnastikforeningerne eller til en moderniseret udgave af ungdomsforeningerne eller er man sả dristig og să forudsigende at give dem til den nye bykultur? Ja, pengene er gaate til gymnastikforeningerne, de har fàet eller fär deres idraetshal og svommebad. I )erfor må man

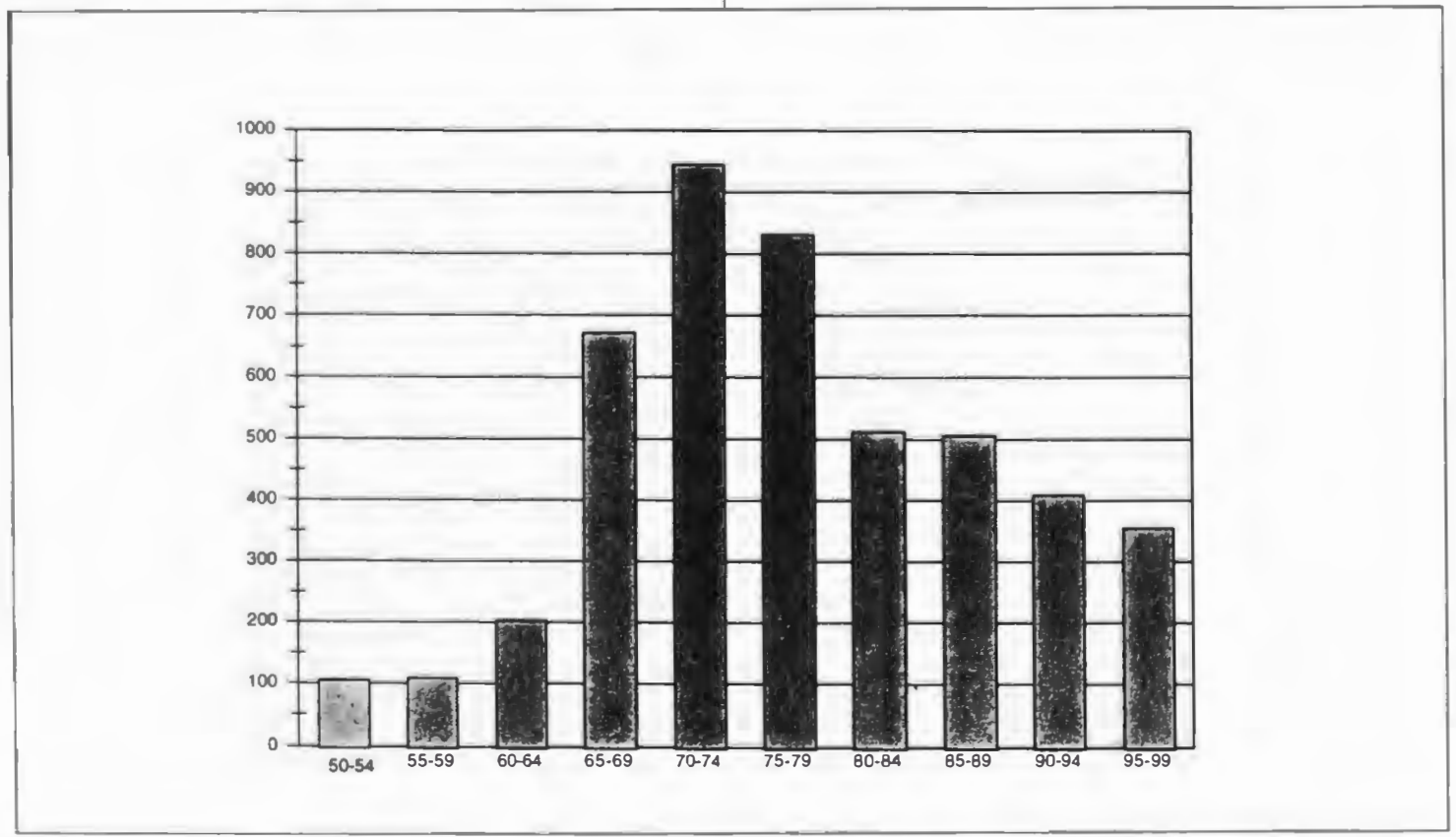

Figur 5: Haller og klublunse i ir 20(0). Bygningshestandens storrelse i 100() m fordele efter bygningsair inden for perioden 195()-1999. Kïlde: Lanmarks Statistiks databank 
spørge, kan der ikke være plads til andet i idrætshallerne end sport [og] kan den nye bykultur ikke lempes ganske stille ind side om side med en ny form for ungdomsarbejde?" ${ }^{\circ 8}$

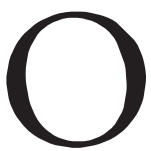
mkring 1970 var ungdomsforeningerne på landet efterhånden svundet helt bort, og med dem mange af de traditionelle, landbrugerprægede foreningsnetværk indenfor det kulturelle foreningsliv. Hermed opstod der tydeligvist et organisationsmæssigt vakuum i landdistrikterne, eftersom de lokale, økonomiske foreninger jo også var blevet kraftigt reducerede.

Op gennem 1970'erne blev det de ofte tilflytterdominerede sogne-, beboerog borgerforeninger, der med brug af en overvejende urban retorik skulle bidrage med at fylde dette vakuum. ${ }^{69}$ Hermed fuldbyrdedes så at sige den kulturelle 'inficering' af landbokulturen, som talrige generationer af landboere havde frygtet. På den anden side måtte den 'oprindelige', landbrugerprægede landbefolkning dog indrømme, at det på dette tidspunkt var nødvendigt med flere tilflyttere - at det var nødvendigt med nye kræfter, nye livsanskuelser, nye drømme.

\section{Noter:}

1. Denne artikel udspringer af et ph.d.-projekt med titlen „Livsvilkår og boligbyggeri i de danske landdistrikter 1950-2000."

Projektet indgår i programmet „Mennesker i det agrare landskab" under Forskningsrådenes tværfaglige forskningsinitiativ „Det agrare landskab i Danmark 1998-2001.“

2. Nærmere om den tidlige foreningsbaserede organisering, se Svendsen 2001, Svendsen $2001 \mathrm{j}$.

3. For en nærmere gennemgang af artiklerne i Dansk Ungdom, se også Svendsen 2001h.

4. J. Kr. la Cour Madsen i Hojskolebladet 1955, s. 209. Samme synspunkter finder vi hos højskoleforstander Erik B. Nissen, Antvorskov (Erik B. Nissen i Dansk Ungdom 1950, s. 207).

5. Gunnar Damgård Nielsen i Dansk Ungdom 1951 , s. 254. For en nærmere gennemgang, se også Svendsen 2001h.

6. Nærmere om egnsudviklingsstøtten og de danske landbrugere, se Svendsen 2001 i.

7. Den afmagtsfølelse, dette skabte hos beboerne i mange småbyer i begyndelsen af 1970'erne, er f.eks. dokumenteret i bogen Landsbyfolk og landsbybevagelse (Thygesen 1979), der består af interviews med ledende kræfter indenfor nyere sogne- og borgerforeninger i 7 landsbyer. Den skattemæssige forskelsbehandling blev da også af De jyske Landboforeningers formand Anders Andersen betegnet som "fuldkomment socialt urimelig" (Anders Andersen i Dansk Landbrug 1968, s. 237).

8. Om nedlæggelse af forsamlingshuse i 1950 'erne og 1960'erne, se f.eks. Thygesen 1979, s. 29. Se også Fabricius 1991, s. 69. Om nedlæggelse af sognebibliotekerne, se f.eks. Hojskolebladet 1960, s. 767; 1961, s. $35 \mathrm{ff}$.

9. Poul Dam i Hojskolebladet 1959, s. 218.

10. Se f.eks. Thygesen 1979, s. 11, 38 og 52ff.; Fabricius 1991, s. 29 og 32; Christiansen 1980, s. 105, 174,328, 335; Nielsen m.fl. 1996, s. 23-24.

11. Hojskolebladet 1939, s. 299. Se f.eks. også 
Hojskolebladet 1938, s. 378.

12. Se f.eks. Hojskolebladet 1938, s. 325, 341, $346,667$.

13. Hojskolebladet 1938, s. 282.

14. Jørgen Bøgh i Tidsskrift for Landokonomi 1960, s. 381. Om bekymringen, se også Hojskolebladet 1951, s. 486. I januar 1954 var bekymringen så stor, at landboforeningerne sendte en henvendelse til regering, folketing og offentlighed for at gøre opmærksom på de dårlige skoleforhold i landdistrikterne (Tidsskrift for Landokonomi 1954, s. 162ff.).

15. Om "strukturændringen i skolen", se f.eks. Højskolebladet 1958, s. 553, 555, 569ff.

16. Om frygten for en for dårlig uddannelse, se f.eks. Hojskolebladet 1960, s. 62. Nærmere om bykulturens 'inficering' af landbokulturen, se Svendsen 2001c, 2001h.

17. Poul Nyboe Andersen i Hojskolebladet 1958, s. 538.

18. For en nærmere gennemgang, se Svendsen $2001 \mathrm{f}$.

19. Poul Nyboe Andersen i Hojskolebladet 1959, s. 259.

20. Poul Nyboe Andersen i Hojskolebladet 1959, s. 259.

21. Citeret fra Husmandshjemmet 1966, nr. 46, s. 8.

22. Tage Rostenstand gengivet i Hojskolebladet 1960 , s. 59. Samstemmende hedder det om Ålstrup skole i Falling sogn syd for Odder: "Skolen som institution er interessant på flere måder. Dels går dens historie helt tilbage til begyndelsen af 1700-årene, dels har skolens lærere spillet en vigtig rolle i samfundet - ikke mindst i forbindelse med de mange nye foreningsdannelser i slutningen af forrige århundrede. Endelig har skolens bygninger været et vigtigt samlingssted i byen - især i dette århundrede" (Fabricius 1991, s. 29). Også

Skovhuse Skole i Rønhave-kolonien på Als fungerede som "husmandsbefolkningens naturlige samlingssted" og blev med tiden "en slags kulturcenter" (Solvang 1999, s. 62).
23. Else Toftkjær Jensen i Hojskolebladet 1959, s. 272. Om fænomenet 'sovebyer', se også Bidstrup og Kaufmann 1966 [1963], s. 148.

24. Møller 1995, s. 288.

25. Møller 1995, s. 288.

26. Møller 1995, s. 287 og 289.

27. Om debatten, se f.eks. Hojskolebladet 1965 , s. $143,155,426,475,523,563,606$. Se også Husmandshjemmet 1966, nr. 9, s. 3.

28. Niels Højlund i Hojskolebladet 1966, s. 428; Uffe Geertsen i Hojskolebladet 1966, s. 475.

29. Uffe Geertsen i Hojskolebladet 1966, s. 477.

30. Om 'sognet i opbrud', se f.eks. Hojskolebladet 1963, s. 233; Dansk Landbrug 1968, s. 162; LOK 1968. På lignende måde taler Helmer Pedersen om 1960'erne som "opbruddets årti" indenfor landbrugserhvervet (Pedersen 1988, s. 234).

31. Christiansen 1980, s. 92.

32. Christiansen 1980, s. 105.

33. Christiansen 1980, s. 94.

34. Christiansen 1980, s. 94.

35. Christiansen 1980, s. 95.

36. Christiansen 1980, s. 172.

37. Christiansen 1980, s. 172.

38. Christiansen 1980, s. 263.

39. Frede Andersen citeret i Husmandshjemmet 1964, nr. 17, s. 9.

40. 'På grund af manglende planlægning er store indtægter allerede gået tabt for landbruget i Danmark. Over hele landet findes planløst sommerhusbyggeri, især langs strande og sørige områder. På Sjælland er 60 pct. af den offentlige strand beslaglagt. Man har berøvet landbrugerne en vare, de kunne sælge hvert år. De mange hoteller landet over ejes ikke af landboere, men er på 89-dages-københavnernes hænder! Ja, sådan kalder jeg de byboere, der slipper for at betale skat på landet, fordi de også har bopæl i byen "(Sten Bjarke citeret i Husmandshjemmet 1968, nr. 15, s. 9).

41. Bidstrup og Kaufmann 1966, s. 58.

42. Bidstrup og Kaufmann 1966, s. 58. 
43. Bidstrup og Kaufmann 1966, s. 146.

44. Bidstrup og Kaufmann 1966, s. 147.

45. Bidstrup og Kaufmann 1966, s. 149.

46. Om forestillingen om 'det globale udviklingskapløb' indenfor andelsbevægelsen, se Svendsen 2001a, 2001b, 2001g.

47. "Udviklingen" indenfor kulturlivet: se f.eks. Dansk Ungdom 1961, s. 287; 1962, s. 31; 1963, s. 286; 1966, s. 103; Hojskolebladet 1963, s. 796. "Nødvendighedens lov": Dansk Ungdom 1965, s. 519. "Strukturændring" indenfor det kulturelle område: se f.eks. Hojskolebladet 1958, s. 553, 569; Dansk Ungdom 1966, s. 102, 793. "Rationalisering": se f.eks. Dansk Ungdom, 1965, s. 519; Dansk Ungdom og Idrat 1967, s. 216. Nærmere om begrebet 'strukturændringer', se Svendsen 2001e.

48. Om ungdommen og fritidsproblemet, se Svendsen $2001 \mathrm{~h}$.

49. "Ungdommens øgede fritid": se f.eks. Dansk Ungdom 1959, s. 72; 1961, s. 287; 1965, s. 38; Dansk Ungdom og Idrat 1967. s. 208, 214. Se f.eks. også Hojskolebladet 1958, s. 141; 1968, s. 183.

50. Se f.eks. Dansk Ungdom 1964, s. 188. Allerede 1959-60 havde der været debat om emnet, lokalt såvel som nationalt, ligesom der flere steder var blevet påbegyndt et formelt samarbejde mellem ungdoms- og gymnastikforeningerne (Dansk Ungdom 1960, s. 482).

51. Se f.eks. Dansk Ungdom 1958, s. 246; 1964, s. 50; Dansk Ungdom og Idrat 1967. s. 300 .

52. "Fritidssamfund": se Dansk Ungdom og Idrat 1967, s. 206, 216; Højskolebladet 1963, s. 68, 539. Om "utidssvarende forsamlingshuse", se f.eks. Dansk Ungdom 1951, s. 14, 283; 1964, s. 50; Dansk Ungdom og Idrat 1967, s. 300.

53. Dansk Ungdom og Idrat 1967, s. 300.

54. Jørgen Banke i Samfundets Krau 1940, s. 89-90. Se også Dansk Ungdom og Idrat 1967, s. 300.

55. Jørgen Banke i Samfundets Krar' 1940, s. 89-90.
56. Dansk Ungdom og Idrat 1967, s. 300.

57. Dansk Ungdom og Idrat 1967, s. 301.

58. Se også Svendsen $2001 \mathrm{~h}$ for en nærmere gennemgang.

59. Se Svendsen 2001 a.

60. Mandøe 1951.

61. Dansk Ungdom 1963, s. 535. ()m debatten om ungdoms-, fritids- og hobbyklubber, se f.eks. også Dansk Ungdom 1953, s. 24; 1956 , s. $90 ; 1959$, s. $214 ; 1964$, s. 185 ; 1966, s. 138; Dansk Ungdom og Idrat 1967 , s. 216,$479 ; 1968$, s. $411 \mathrm{ff}$.

62. Viggo Vandkær Thomsen i Dansk Ungdom 1959, s. 72.

63. Viggo Vandkær Thomsen i Dansk Ungdom 1961, s. 288.

64. Peter Madsen i Dansk Ungdom 1966, s. 344.

65. Dansk Ungdom og Idrat 1967, s. 207. ( )m de nye haller, se f.eks. ogsă Dansk Ungdom 1965, s. 595ff.; Dansk Ungdom og Idrat 1967, s. $299 \mathrm{ff} . ; 1968$, s. 534.

66. Dansk Ungdom og Idrat 1967, s. 206.

67. Flemming Hemmersam i Dansk Ungdom og Idret 1967, s. 302.

68. Flemming Hemmersam i Dansk Ungdom og Idrat 1967, s. 302 .

69. For en nærmere gennemgang, se Svendsen 2001d.

\section{Litteratur:}

Bidstrup, Knud og Erik Kaufmann (1966) Danmark under for'andling. Danmarks Radios Grundboger, Fremad. Det Hoffensbergske Etablissement, Khh.

Christiansen, Palle Ove (1980) Fire Landsbyer. En etnologisk rapport om nutidige lin'sformer. Landsbykommissionen.

Dansk Landbrug. Årgang 1968.

Dansk Ungdom. Argangene 1950-51, 1953. 1956, 1959-66.

Dansk Ungdom og Idrat. Argangene 196־-68.

Fabricius, Nina (1991) I'i by'ggede sele l'ores samfund. Odder Museum, Esbjerg. Husmandshjemmet. Argangene 1964, 1)(26, 
1968.

Hojskolebladet. Årgangene 1938-39, 1951, 1955, 1958-61, 1963, 1965-66.

L()K - Landbrugets Oplysnings- og Kursusvirksomhed (1968) Landsognet i opbrud.

Mandoe, Asbjorn (1951) "Sognegården onskedrom eller mareridt?" Kronik i Jyllandsposten 17/6, 1951.

Moller, Per Grau (1995) "Kommunalreformen 197() og kulturlandskabet." I: Folk og erhnern', s. 287-29). Odense Universitetsforlag.

Nielsen, Dorte, Helene Oldrup og Hanne W. Tanvig (1996) Liv' i landet. Sydjysk Universitetsforlag. Esbjerg Offset ApS, Esbjerg.

Pedersen, Erik Helmer (1988) Det danske landbrugs historie, bd. 3 (1914-1988). Landbohistorisk Selskab. AiO Tryk, ()dense.

Sumfundets Kraur. Årgang 1940.

Solvang, (iunnar (1999) Husmandsliv' under afrikling. L'drikling og forandring $i$ et sonderjysk landbosamfund 1975-2000 med hoveduregt pă de nye tilflyttere. Fra Als og Sundeved, bd. 77. Landbohistorisk Selskab, Historisk Samfund for Als og Sundeved, Viborg.

Svendsen, Gunnar Lind Haase (2001)

"Historien anskuet som et kapitalmarked. Selvorganiseringen i de danske landdistrikter 180()-19()()". Fortid og Nutid, nr. 1, s. 23-51.

Svendsen, Gunnar Lind Haase (2001a)

"Livsformer i landdistrikterne. Den evindelige spænding mellem det traditionelle og det moderne". Udkommer i Bol og By, nr. 2 .

Svendsen, Gunnar Lind Haase (2001b)

"Andelsbevægelsen og den hvide mands byrde. Et bidrag til en antropologiskhistorisk belysning af dansk u-landsbistand 1960-70". Udkommer i Historie, 2002.
Svendsen, Gunnar Lind Haase (2001c) "De danske ungdomsforeninger og kampen mellem land og by". Udkommer i Fortid og Nutid, 2002, nr. 3.

Svendsen, Gunnar Lind Haase (2001d) „Retten til udvikling. Skreddet fra pligt til krav i den danske landbefolkning 1977 78". Udkommer i Den jyske Historiker; 2002, nr. 100.

Svendsen, Gunnar Lind Haase (2001e) "Hvad er strukturændringer?" Til redaktionel bedømmelse i Samfundsokonomen.

Svendsen, Gunnar Lind Haase (2001f) "Driften mod stordrift. Argumenterne for og imod centralisering indenfor andelsbevægelsen 1950-70". Upubliceret artikel.

Svendsen, Gunnar Lind Haase (2001g) "Dansk mejeribrug og udviklingens lov 1950-70". Til redaktionel bedømmelse i Historie.

Svendsen, Gunnar Lind Haase (2001h) "Den usunde strøm fra byerne. Krisen indenfor De danske Ungdomsforeninger 1950-70". Til redaktionel bedømmelse i Folk og Kúltur.

Svendsen, Gunnar Lind Haase (2001i) "Egnsudvikling eller industriudvikling? De danske husmænd og velfærdssamfundet 1960-1970". Til redaktionel bedømmelse i Økonomi is Politik.

Svendsen, Gunnar Lind Haase (2001j) „Hundrede års selvorganisering”. Udkommer i Siden Saxo, 2002, nr. 1.

Thygesen, Erik (1979) Landsbyfolk og Landsbybevægelse. Forlaget Beboertryk, Kbh.

Tidsskrift for Landokonomi. Årgangene 1954 og 1960.

Ungdomskommissionen (1951) Fritidslokaler på landet. Betænkning nr. 11. J.H. Schultz $\mathrm{A} / \mathrm{S}, \mathrm{Kbh}$.

Ungdomskommissionen (1952) Ungdommen og Fritiden. Betænkning nr. 12. J.H.

Schultz A/S, Kbh. 